\title{
A meta-analysis of transcriptomic characterization revealed extracellular matrix pathway involved in the H5N1 and H7N9 infections
}

\author{
Feng Wen ${ }^{1}$, Jinyue Guo ${ }^{2}$, Guangzhi Tong ${ }^{1,3}$, Dingren $\mathrm{Bi}^{2}$, Qi Wang ${ }^{1}$, Xiaomin Liu ${ }^{1}$, \\ Shuaiyong Wang ${ }^{1}$, Tonglin Shan ${ }^{1}$, Wu Tong ${ }^{1}$, Yanjun Zhou ${ }^{1}$, Guoxin Li $^{1}$ and Hai \\ $\mathbf{Y} \mathbf{u}^{1,3}$
${ }^{1}$ Division of Swine Infectious Diseases, Shanghai Veterinary Research Institute, Chinese Academy of Agricultural Sciences, Shanghai 200241, China
${ }^{2}$ College of Veterinary Medicine, Huazhong Agricultural University, Wuhan 430070, China
3 Jiangsu Co-innovation Center for Prevention and Control of Important Animal Infectious Diseases and Zoonoses, Yangzhou 225009, China
Correspondence to: Jinyve Guo, email: guojinyve12@163.com
Hai Yu, email: haiyu@shvri.ac.cn
Keywords: influenza A, H7N9, H5N1, meta-analysis, extracellular matrix
Received: April 04, $2017 \quad$ Accepted: June 16, $2017 \quad$ Published: July 18, 2017
Copyright: Wen et al. This is an open-access article distributed under the terms of the Creative Commons Attribution License 3.0 (CC BY 3.0), which permits unrestricted use, distribution, and reproduction in any medium, provided the original author and source are credited.

\section{ABSTRACT}

Avian-origin H5N1 and H7N9 influenza A viruses are capable of causing lethal infection in humans, with serious lung pathology and leading to acute respiratory distress syndrome. The contribution of host response associated with the poor prognosis of H5N1 and H7N9 infections remains unclear. The aim of this study was to identify the host factors involved in the high pathogenicity of H5N1 and H7N9 by a systematical meta-analysis. The RNA-seq datasets related to H5N1, H7N9, and H1N1 infections with time series were retrieved from GEO. After merging the data from different series, ComBat was used to adjust the known variances from different batches. The transcription factors binding the genes in each cluster were predicted by PASTAA. We figured out the genes that were differentially expressed at any time point in samples infected with H5N1, H7N9, or H1N1. The analysis of biological function showed that genes related with cytokine were up-regulated in all three viruses. However, genes associated with carbon metabolism were found exclusively downregulated in H7N9 and the extracellular matrix pathway were only enriched in H5N1 and H7N9. To summary, our study suggested that the extracellular matrix might be associated with the high fatality of H5N1 and H7N9 viruses in humans.

\section{INTRODUCTION}

Avian influenza, the infections of birds with avian influenza type A viruses (IAVs), occurred naturally among wild aquatic birds worldwide. Avian influenza viruses do not commonly infect humans, but human infections are reported sporadically. Recently, outbreaks of human infections after contact with infected birds or their secretion or through limited person-to-person transmission caused the attention of the public. Following the first appearance of the H5N1 in 1997, the H7N9, H10N8, and H5N6 subtypes of influenza A virus were detected following under the ongoing surveillance efforts, which have all caused severe infections [1].

Among all avian IAVs, H7N9 and H5N1 have been responsible for most human infections worldwide to date, including the most serious illnesses and deaths. Since the first recognized human case of H5N1 infection in 1997, the World Health Organization (WHO) has reported 854 confirmed human infection cases as of July 2016, with a fatality rate of about $66 \%[1,2]$. Besides, a total of 1307 laboratory-confirmed human infections with the H7N9 has been reported through the notification of the International 
Health Regulations (IHR) since early 2013 with a fatality rate of $40.4 \%[1,3]$. More than 400 additional laboratoryconfirmed cases of human infection have been reported to WHO from China in the recent months since 2017 [4]. Fortunately, both H5N1 and H7N9 were reported to have limited potential for human-to-human transmission, but it might gain the ability to spread between people through the antigenic shift or antigenic drift. Such risk urged us to prevent and cure the infection of $\mathrm{H} 5 \mathrm{~N} 1$ and $\mathrm{H} 7 \mathrm{~N} 9$.

Unlike the common seasonal flu, H5N1 and H7N9 viruses were highly pathogenic. H5N1 was highly pathogenic in both human beings and birds [5], while H7N9 seemed to exhibit low pathogenicity in birds with the severe disease that occurs in human [6]. There was more H7N9 human infections than $\mathrm{H} 5 \mathrm{~N} 1$, partly because of asymptomatic infection of $\mathrm{H} 7 \mathrm{~N} 9$ caused by the transmission through direct contact with seemingly healthy but infected birds [7]. FDA approved the first monovalent adjuvanted vaccine for prevention of H5N1 avian influenza in 2013 [8]. This vaccine could be used in the event that the $\mathrm{H} 5 \mathrm{~N} 1$ avian influenza virus develops the capability of efficient humanhuman transmission. However, there currently is no publicly available vaccine to protect against $\mathrm{H} 7 \mathrm{~N} 9$ virus infection [9].

For $\mathrm{H} 5 \mathrm{~N} 1$ and $\mathrm{H} 7 \mathrm{~N} 9$, the exact contribution of individual viral effect to pathogenicity at the molecular level is still largely unknown, which is certainly helpful to decrease the fatality. Microarray is a useful tool to understand their infection at the level of transcriptional regulation in the host cells which is important for the interpretation of these complex genetic changes [10]. However, a lot of studies have reported that findings of microarray data were not reproducible or were sensitive to the data perturbations [11, 12]. Moreover, microarray used over 10 thousand probes on tens or hundreds of samples, which exacerbated the accuracy of the potential predictors. As a result, a meta-analysis was used to increase the reliability and generalizability of results.

Through this meta-analysis, we aimed to obtain a more precise set of differentially expressed genes and analyze their biological functions. In this study, we utilized the 6 and 2 available public microarray datasets from Gene Expression Omnibus (GEO) repository [13] for H5N1 and $\mathrm{H} 7 \mathrm{~N} 9$, respectively, to figure out the genes which were differentially expressed in cell lines infected with influenza virus and control. Another two datasets of H1N1 were analyzed as a comparison, so that we were able to figure out the possible cause of the high pathogenicity of $\mathrm{H} 5 \mathrm{~N} 1$ and $\mathrm{H} 7 \mathrm{~N} 9$ and point out the direction to clinical treatment.

\section{RESULTS}

\section{The data pre-processing for microarray meta- analysis}

As the basis for the meta-analysis, there were totally 6 and 2 GEO datasets with time series available for H5N1 and $\mathrm{H} 7 \mathrm{~N} 9$ respectively and we also selected another 2 datasets from H1N1 to compare the avian influenza with the 2009 pandemic flu in order to figure out why H5N1 and H7N9 were so pathogenic (Table 1).

Because it was generally agreed that microarray data from distinct experimental platforms, often using distinct reference samples, are not directly comparable, we used some strategies to overcome it. After background correction and quantile normalization, the expression level of each gene was estimated by the median of the expression levels of all the probes mapped to it. Next, ComBat was utilized to adjust the known dataset differences with an empirical Bayesian framework. The hierarchical clustering of the expression profiles before and after adjustment indicated that our strategies worked for meta-analysis. Before adjustment, the samples from the same datasets were clustered together (Figure 1A, 1C). But after adjustment, the samples from the same time points were the closest to each other (Figure 1B, 1D) with an exception for dataset GEO66597 and the 7h time point. Considering its aberrant clustering performance and the fact that the cell line used in GEO66597 were different from other studies, which meant that they used different tissues as a target, we decided to remove it from the following studies. The $12 \mathrm{~h}$ and $24 \mathrm{~h}$ time points of $\mathrm{H} 5 \mathrm{~N} 1$ were clustered together well (Figure 1B), but only $24 \mathrm{~h}$ time point of H7N9 were clustered together. This suggested two possibilities: first, the limited datasets for H7N9 constrained the performance; and second, the cells might need more time to react when infected with H7N9 than H5N1.

The principal component analysis also showed the time points were the largest possible variance for H5N1 where H7N9 were not shown but had similar results as H5N1 (Figure 2A).

\section{Identification of differentially expressed genes using microarray meta-analysis}

First, we calculated the Pearson correlation of each time point for $\mathrm{H} 5 \mathrm{~N} 1$ and $\mathrm{H} 7 \mathrm{~N} 9$. As expected, the internal variance increased as the time passed (Figure 2B, H7N9 not shown). The differentially expressed genes were identified for each time point of H5N1, H7N9, and H1N1. The count of genes significantly up-regulated or downregulated in every group were plotted as Figure 2C.

The KEGG pathways were enriched for the upregulated or down-regulated genes in $\mathrm{H} 5 \mathrm{~N} 1, \mathrm{H} 7 \mathrm{~N} 9$, and H1N1 virus strain. Figure 3 showed the enriched pathways for $\mathrm{H} 5 \mathrm{~N} 1$ and the pathways enriched for $\mathrm{H} 7 \mathrm{~N} 9$ and H1N1 were available in Table 2. The Cytokine-cytokine receptor interaction, Toll-like receptor signaling pathway, Cytosolic DNA-sensing pathway and Influenza A pathway were all up-regulated in cells infected with three virus strains. These results suggested that the cells were using chemokine and cytokines to defense the virus. But the down-regulated genes of the three viruses had different patterns. There were no down-regulated genes available for $\mathrm{H} 1 \mathrm{~N} 1$, and no enriched pathway for $\mathrm{H} 5 \mathrm{~N} 1$, while the down-regulated genes in H7N9 were associated with metabolism. 
Table 1: The information of the GEO datasets analyzed in this study

\begin{tabular}{lccccc}
\hline Strain $^{\mathbf{a}}$ & GEO accession & Platform & Submission date & Pubmed ID & Cell Line \\
\hline & GSE76599 & GPL13497 & Jan 06 2016 & & Calu-3 \\
& GSE66597 & GPL6480 & Mar 06 2015 & 26008703 & U251 \\
H5N1 & GSE49840 & GPL17077 & Aug 13 2013 & 24496798 & Calu-3 \\
& GSE43203 & GPL6480 & Dec 29 2012 & & Calu-3 \\
& GSE43204 & GPL6480 & Dec 29 2012 & & Calu-3 \\
& GSE28166 & GPL6480 & Mar 24 2011 & 21865398 & Calu-3 \\
H7N9 & GSE49840 & GPL17077 & Aug 13 2013 & 24496798 & Calu-3 \\
& GSE69026 & GPL13497 & May 19 2015 & & Calu-3 \\
H1N1 & GSE80697 & GPL13497 & Apr 26 2016 & & Calu-3 \\
& GSE40844 & GPL6480 & Sep 12 2012 & & Calu-3 \\
\hline
\end{tabular}

a The virus strains selected in this study were: A/Vietnam/1203/2004 (H5N1); A/Anhui/01/2013 (H7N9); A/ California/04/2009 (H1N1).

${ }^{\mathrm{b}}$ The dataset annotated was not in the analysis considering it was aberrant after normalization and batch adjustment.
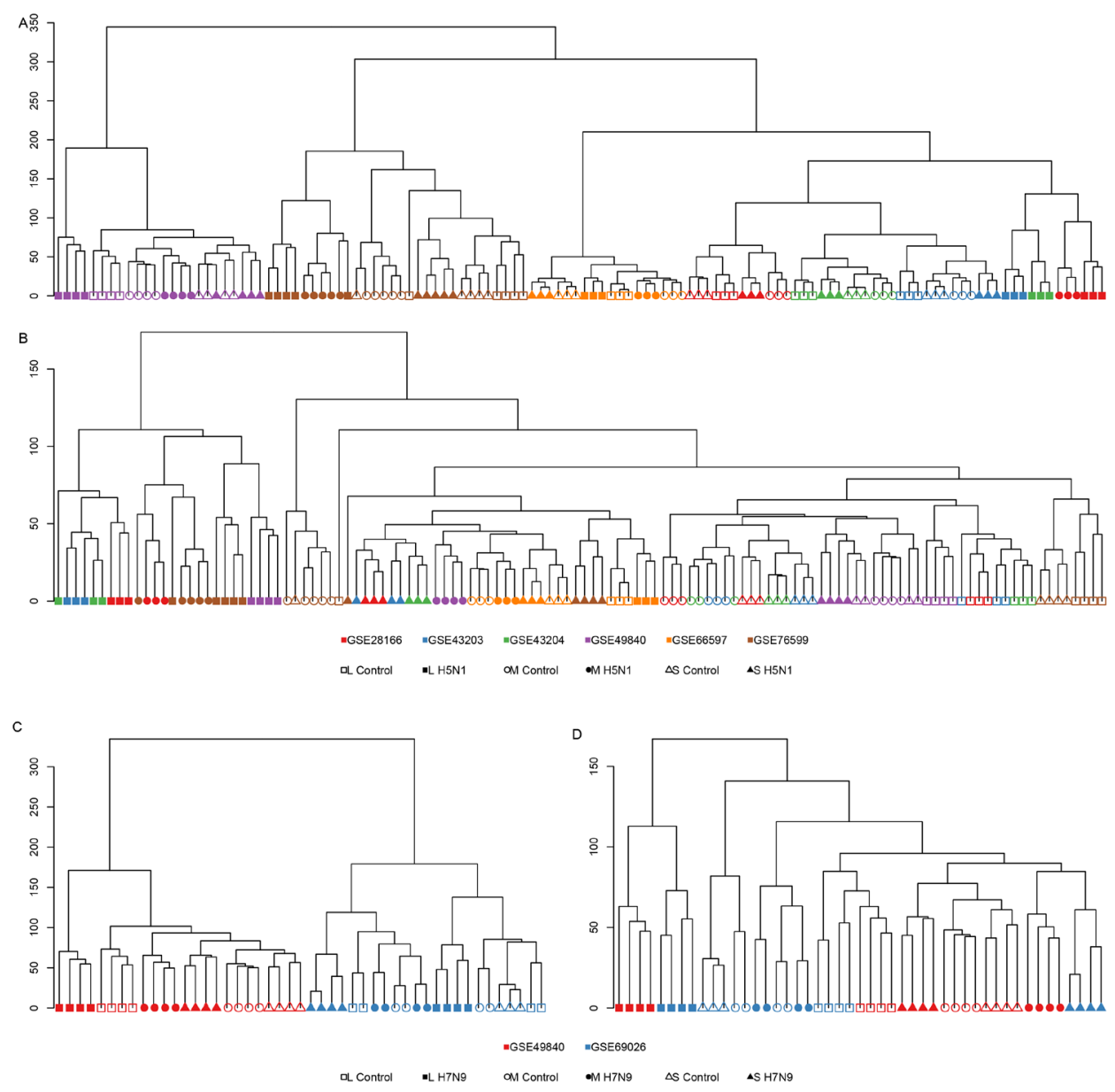

Figure 1: The hierarchical clustering of gene expression levels. (A) and (B) showed the clustering of H5N1 datasets before (A) and after (B) batch adjustment. (C) and (D) showed the clustering of H7N9 datasets before and after batch adjustment. The different GEO series were annotated by different colors and different time points were annotated as different shapes. Hollow and solid symbols represented the samples with mock infection and with virus infection. 


\section{Identification of clusters of expression profiles in virus strains}

The fold changes of genes that were differentially expressed in any strain were utilized to decide the clusters of the expression profiles (Figure 4). The expression levels of most genes were only changed dramatically in $24 \mathrm{~h}$ time point. Moreover, the correlation between $\mathrm{H} 5 \mathrm{~N} 1$ and $\mathrm{H} 7 \mathrm{~N} 9$ at $24 \mathrm{~h}$ time point (Pearson correlation: 0.82) were higher than the correlation between H5N1 and H1N1 (Pearson correlation: 0.61 ) or H7N9 and H1N1(Pearson correlation: $0.59)$. It suggested that $\mathrm{H} 5 \mathrm{~N} 1$ and $\mathrm{H} 7 \mathrm{~N} 9$, both of which were avian influenza viruses, were more similar to each other.

Finally, we obtained 10 clusters based on their expression profiles in $\mathrm{H} 5 \mathrm{~N} 1, \mathrm{H} 7 \mathrm{~N} 9$, and $\mathrm{H} 1 \mathrm{~N} 1$. Based on the genes involved in 10 clusters, the involved pathways and the enriched transcript factors were summarized in Table 3. Some clusters did not have enriched pathway or transcript factors, which might by led from a few genes involved. The only pathways enriched for up- regulated clusters were Influenza A pathways and most of the transcript factors belonged to interferon regulatory transcription factor (IRF) family. It suggested that the upregulated genes were highly associated with the interferon regulation and were common in both avian influenza and pandemic flu. Besides, Sta5a and Sta5b mediate cellular responses to the cytokine KITLG/SCF and other growth factors, which might help to fight against infection.

However, the down-regulated clusters had different performance. First, cells infected H1N1 viruses did not have any down-regulated genes in this study surprised but it might be caused by the strict criteria for differentially expressed genes and the large amount of up-regulated genes. Second, the genes only down-regulated in H7N9 were highly associated with metabolic pathways, while the genes down-regulated in both $\mathrm{H} 7 \mathrm{~N} 9$ and $\mathrm{H} 5 \mathrm{~N} 1$ were related to the extracellular matrix pathway. Though there was no pathway enriched for genes only low-expressed in $\mathrm{H} 5 \mathrm{~N} 1$, the transcript factor $\mathrm{Creb}$ and $\mathrm{Creb} \beta$ might have an impact.

B
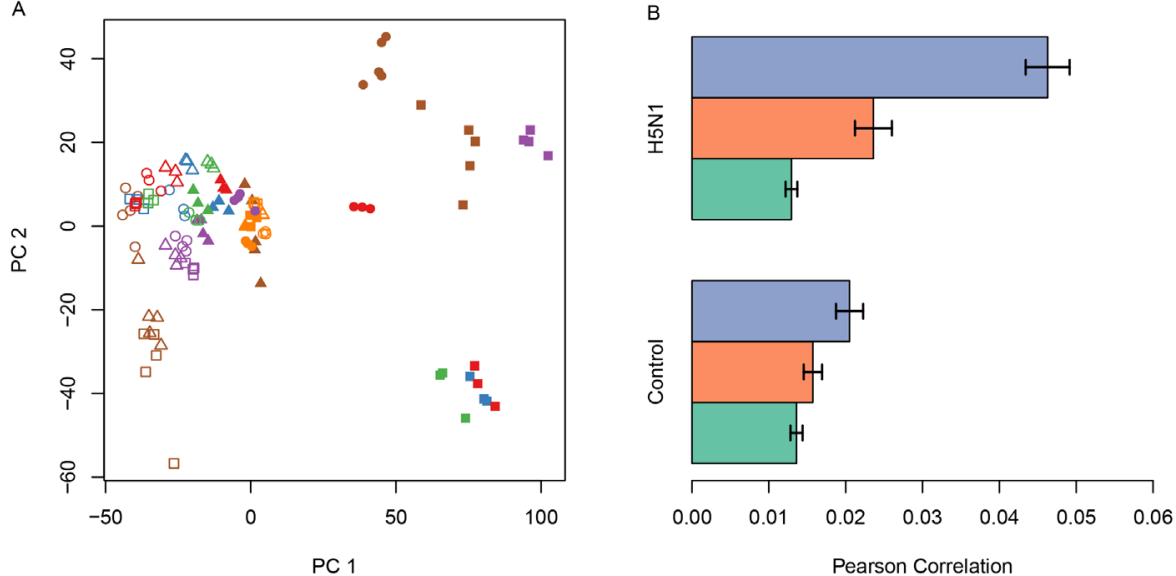

Pearson Correlation

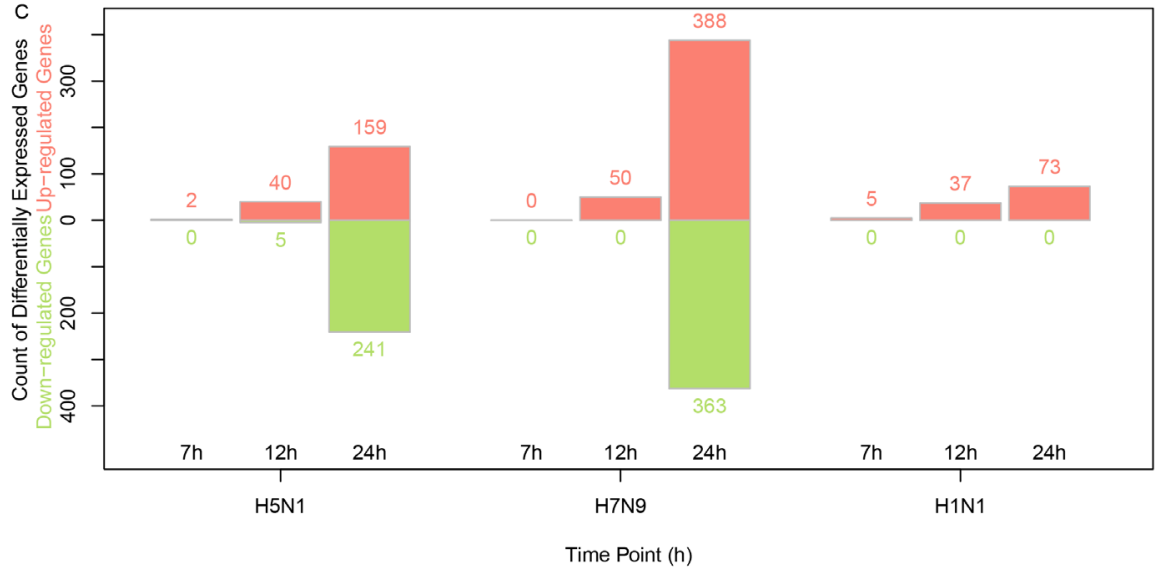

Figure 2: The correlations between H5N1 expression levels and the differentially expressed genes in infected samples. (A) The principal component analysis of $\mathrm{H} 5 \mathrm{~N} 1$ datasets showed that samples with $\mathrm{H} 5 \mathrm{~N} 1$ infections after $12 \mathrm{~h}$ or $24 \mathrm{~h}$ were specific to other samples. (B) The average distances between H5N1-infected samples and time-matched infected or mock samples. The x-axis was the Pearson correlation distance and error bars indicated standard deviation. (C) The count of genes which were up-regulated or downregulated in $\mathrm{H} 5 \mathrm{~N} 1, \mathrm{H} 7 \mathrm{~N} 9$ and $\mathrm{H} 1 \mathrm{~N} 1$ using red and green, respectively. 


\section{DISCUSSION}

Influenza viruses can be categorized as either low pathogenicity or high pathogenicity based on their ability to induce disease in a specific host. A better understanding of mechanisms that may lead to severe illness or death caused by high pathogenicity H5N1 or H7N9 would benefit the treatment of those infections when happens in humans. Studies of differences in the host response to different virus strains would provide insight into why viruses exhibit severe damage to then certain host. In this study, we preformed a meta-analysis to evaluate the host response to two high pathogenicity $\mathrm{H} 5 \mathrm{~N} 1$ and $\mathrm{H} 7 \mathrm{~N} 9$ avain influenza viruses with the comparison with the seasonal flu H1N1, which have been reported to cause high mortality in human infection cases.

As describe in the results, cells infected with $\mathrm{H} 5 \mathrm{~N} 1, \mathrm{H} 7 \mathrm{~N} 9$, and H1N1 shared the similar functions of up-regulated genes. They were the cytokine-cytokine receptor interaction, Toll-like receptor signaling pathway, cytosolic DNA-sensing pathway and influenza A pathway. The transcription factors were also similar which were associated with the interferon regulatory transcription factor (IRF) family. As expected, most of the up-regulated genes were associated with the immune system against infection. However, the down-regulated genes showed various patterns for $\mathrm{H} 5 \mathrm{~N} 1$ and $\mathrm{H} 7 \mathrm{~N} 9$, while there were no down-regulated genes in H1N1.

A

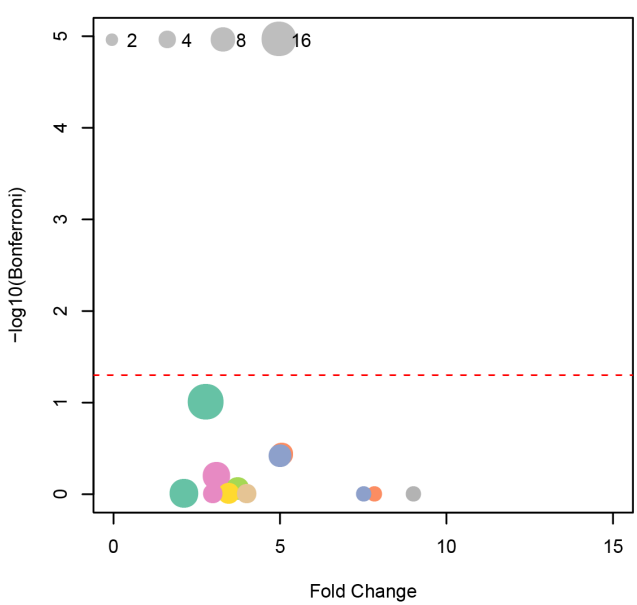

We failed in obtaining the enriched pathway for the genes that were only down-regulated in H5N1. In order to understand their function in another way, we also utilized STRING v10 as an alternative to look at their network status and GO enrichment [14]. It showed that these genes were significantly related with positive regulation of cell migration and negative regulation of cell differentiation. And also these genes seemed to have significantly more interactions than expected, which indicated that the genes were at least partially biologically connected as a group. As a result, we could conclude that the low-expression of these genes would increase cell differentiation and decrease cell migration, which in further might be related with virus-elicited inflammatory and immune reactions.

The cluster with genes only down-regulated in H7N9 was associated with metabolic pathways, especially the carbon metabolism. Qin, Zhang [15] also reported that H7N9 infection could be linked to saccharide or polysaccharide metabolism. It also reported that central metabolism could be strongly affected by virus infections [16]. Besides, biosynthesis of amino acid was also enriched. Thus, the carbon synthesis and amino acid synthesis might be essential to the virus replication of H7N9.

Finally, the down-regulated genes shared by H5N1 and $\mathrm{H} 7 \mathrm{~N} 9$ were related with the extracellular matrix. The KEGG pathway, the extracellular matrix (ECM), was defined as a complex mixture of structural and functional macromolecules and serving an important

B

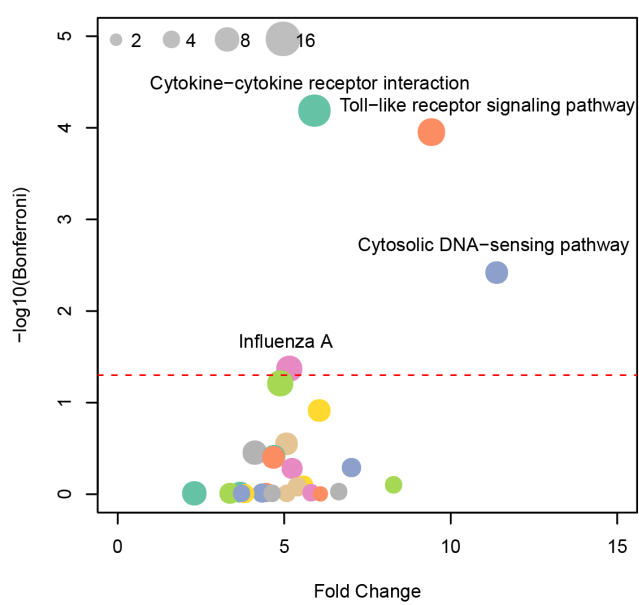

C

\begin{tabular}{|c|c|c|c|c|c|}
\hline Pathway ID & Description & Count & Fold Enrichment & PValue & Bonferroni \\
\hline hsa04060 & Cytokine-cytokine receptor interaction & 14 & 5.77 & $4.90 \mathrm{e}-07$ & $6.66 \mathrm{e}-05$ \\
\hline hsa04620 & Toll-like receptor signaling pathway & 10 & 9.31 & $8.48 \mathrm{e}-07$ & $1.15 \mathrm{e}-04$ \\
\hline hsa04623 & Cytosolic DNA-sensing pathway & 7 & 11.28 & $2.85 \mathrm{e}-05$ & $3.87 \mathrm{e}-03$ \\
\hline hsa05164 & Influenza A & 9 & 5.05 & $3.30 \mathrm{e}-04$ & $4.38 \mathrm{e}-02$ \\
\hline
\end{tabular}

Figure 3: The pathway enrichment for differentially expressed genes in H5N1. (A) and (B) showed the fold change and negative logarithm of Bonferroni as $\mathrm{x}$-axis and y-axis. And the size of point indicated the genes involved in this pathway. (C) The details of significant pathways. 
Table 2: Enriched pathways for up and down-regulated genes

\begin{tabular}{|c|c|c|c|c|c|c|c|c|c|}
\hline Category & Term & Count & P Value & Genes & $\begin{array}{l}\text { List } \\
\text { total }\end{array}$ & Pop hits & $\begin{array}{l}\text { Fold } \\
\text { enrichment }\end{array}$ & Bonferroni & FDR \\
\hline \multicolumn{10}{|l|}{ h7n9 up } \\
\hline $\begin{array}{l}\text { KEGG }_{-} \\
\text {PATHWAY }\end{array}$ & $\begin{array}{c}\text { hsa01100:Metabolic } \\
\text { pathways }\end{array}$ & 63 & $\begin{array}{l}2.63 \mathrm{E}- \\
08\end{array}$ & $\begin{array}{l}\text { LDHA, ALG1, HEXB, } \\
\text { HLCS, ALG8, AUH, } \\
\text { FDFT1, AKR1C3, } \\
\text { MTHFD1, PIGK, } \\
\text { IDH3G, RPN1, } \\
\text { SUCLA2, DHCR24, } \\
\text { PTDSS2, PLD1, } \\
\text { ACO1, ALDH5A1, } \\
\text { PFKP, NADSYN1, } \\
\text { DPAGT1, PIGT, } \\
\text { PFKM, GMPS, PIGO, } \\
\text { GNS, MAN2A1, } \\
\text { PLCE1, PGM1, } \\
\text { RRM1, PCCB, EXT2, } \\
\text { ALDOA, GALNT2, } \\
\text { NAGLU, GANAB, } \\
\text { CYP51A1, POLA2, } \\
\text { HADHA, ISYNA1, } \\
\text { STT3A, DHCR7, } \\
\text { PEMT, IDH2, FASN, } \\
\text { B3GNT3, ACSL4, } \\
\text { PAPSS2, GBA, ENO1, } \\
\text { FH, DGKQ, MAOB, } \\
\text { TKT, ACSM3, MPI, } \\
\text { MTR, PHGDH, } \\
\text { ALDH2, ALOX5, } \\
\text { PGK1, CBS, PYGB }\end{array}$ & 170 & 1158 & 1.964309662 & $5.93 \mathrm{E}-06$ & $3.36 \mathrm{E}-05$ \\
\hline $\begin{array}{l}\text { KEGG_- } \\
\text { PATHWAY }\end{array}$ & $\begin{array}{c}\text { hsa01130:Biosynthesis } \\
\text { of antibiotics }\end{array}$ & 22 & $\begin{array}{l}1.08 \mathrm{E}- \\
07\end{array}$ & $\begin{array}{c}\text { ALDOA, LDHA, } \\
\text { ACO1, CYP51A1, } \\
\text { PFKP, TKT, PFKM, } \\
\text { HADHA, FDFT1, } \\
\text { ISYNA1, IDH3G, } \\
\text { PGM1, PHGDH, } \\
\text { ALDH2, IDH2, PGK1, } \\
\text { SUCLA2, PAPSS2, } \\
\text { PCCB, CBS, ENO1, } \\
\text { FH }\end{array}$ & 170 & 201 & 3.951887621 & $2.45 \mathrm{E}-05$ & $1.38 \mathrm{E}-04$ \\
\hline $\begin{array}{l}\text { KEGG_- } \\
\text { PATHWAY }\end{array}$ & $\begin{array}{c}\text { hsa01230:Biosynthesis } \\
\text { of amino acids }\end{array}$ & 12 & $\begin{array}{l}2.27 \mathrm{E}- \\
06\end{array}$ & $\begin{array}{c}\text { ALDOA, IDH3G, } \\
\text { ACO1, MTR, } \\
\text { PHGDH, IDH2, PFKP, } \\
\text { TKT, PFKM, PGK1, } \\
\text { CBS, ENO1 }\end{array}$ & 170 & 69 & 6.279283887 & $5.14 \mathrm{E}-04$ & 0.00290813 \\
\hline $\begin{array}{l}\text { KEGG }_{-} \\
\text {PATHWAY }\end{array}$ & $\begin{array}{l}\text { hsa01200:Carbon } \\
\text { metabolism }\end{array}$ & 14 & $\begin{array}{l}6.98 \mathrm{E}- \\
06\end{array}$ & $\begin{array}{l}\text { ALDOA, ACO1, } \\
\text { PFKP, TKT, PFKM, } \\
\text { HADHA, IDH3G, } \\
\text { PHGDH, IDH2, } \\
\text { PGK1, SUCLA2, } \\
\text { PCCB, FH, ENO1 }\end{array}$ & 170 & 108 & 4.680392157 & 0.0015757 & 0.0089203 \\
\hline \multicolumn{10}{|l|}{ h7n9 down } \\
\hline $\begin{array}{l}\text { KEGG_- } \\
\text { PATHWAY }\end{array}$ & $\begin{array}{l}\text { hsa05168:Herpes } \\
\text { simplex infection }\end{array}$ & 15 & $\begin{array}{l}1.49 \mathrm{E}- \\
06\end{array}$ & $\begin{array}{c}\text { IL6, TNF, SP100, } \\
\text { CREBBP, NFKBIA, } \\
\text { OAS1, OAS2, CFP, } \\
\text { IFIT1, IFNB1, IRF7, } \\
\text { JUN, IFNA4, SRSF8, } \\
\text { IFNA8 }\end{array}$ & 110 & 170 & 4.923529412 & $2.53 \mathrm{E}-04$ & 0.00181355 \\
\hline
\end{tabular}

(Continued) 


\begin{tabular}{|c|c|c|c|c|c|c|c|c|c|}
\hline Category & Term & Count & P Value & Genes & $\begin{array}{l}\text { List } \\
\text { total }\end{array}$ & Pop hits & $\begin{array}{c}\text { Fold } \\
\text { enrichment }\end{array}$ & Bonferroni & FDR \\
\hline $\begin{array}{l}\text { KEGG_- } \\
\text { PATHWAY }\end{array}$ & hsa05164:Influenza A & 14 & $\begin{array}{l}4.52 \mathrm{E}- \\
06\end{array}$ & $\begin{array}{l}\text { IL6, TNF, CREBBP, } \\
\text { NFKBIA, OAS1, } \\
\text { OAS2, CXCL10, } \\
\text { IFNB1, TNFRSF10D, } \\
\text { IRF7, JUN, IFNA4, } \\
\text { IFNA8, MX1 }\end{array}$ & 110 & 161 & 4.852173913 & 7.69E-04 & 0.0055202 \\
\hline $\begin{array}{l}\text { KEGG_- } \\
\text { PATHWAY }\end{array}$ & $\begin{array}{l}\text { hsa04620: Toll-like } \\
\text { receptor signaling } \\
\text { pathway }\end{array}$ & 11 & $\begin{array}{c}7.12 \mathrm{E}- \\
06\end{array}$ & $\begin{array}{l}\text { IL6, TNF, LY96, } \\
\text { IFNB1, JUN, IRF7, } \\
\text { IFNA4, NFKBIA, } \\
\text { IFNA8, CD14, } \\
\text { CXCL10 }\end{array}$ & 110 & 97 & 6.327835052 & 0.00121 & 0.00868811 \\
\hline $\begin{array}{l}\text { KEGG_- } \\
\text { PATHWAY }\end{array}$ & hsa05162:Measles & 12 & $\begin{array}{l}1.33 \mathrm{E}- \\
05\end{array}$ & $\begin{array}{l}\text { IL6, TNFRSF10D, } \\
\text { IFNB1, IRF7, IFNA4, } \\
\text { NFKBIA, IL13, } \\
\text { OAS1, OAS2, IFNA8, } \\
\text { MX1, TNFAIP3 }\end{array}$ & 110 & 127 & 5.272440945 & 0.0022503 & 0.01616612 \\
\hline $\begin{array}{l}\text { KEGG_- } \\
\text { PATHWAY }\end{array}$ & $\begin{array}{c}\text { hsa04622:RIG-I-like } \\
\text { receptor signaling } \\
\text { pathway }\end{array}$ & 9 & $\begin{array}{c}1.66 \mathrm{E}- \\
05\end{array}$ & $\begin{array}{c}\text { TNF, ISG15, IFNB1, } \\
\text { IRF7, IFNA4, } \\
\text { NFKBIA, IFNA8, } \\
\text { DHX58, CXCL10 }\end{array}$ & 110 & 65 & 7.726153846 & 0.0028259 & 0.02030615 \\
\hline $\begin{array}{l}\text { KEGG_- } \\
\text { PATHWAY }\end{array}$ & $\begin{array}{l}\text { hsa04060:Cytokine- } \\
\text { cytokine receptor } \\
\text { interaction }\end{array}$ & 15 & $\begin{array}{l}2.83 \mathrm{E}- \\
05\end{array}$ & $\begin{array}{c}\text { CSF2, IL6, TNF, } \\
\text { PDGFA, IL13, IL11, } \\
\text { CXCL10, CCR7, } \\
\text { IL23A, IL20RB, } \\
\text { IFNB1, IFNA4, } \\
\text { CX3CR1, IFNA8, LTB }\end{array}$ & 110 & 219 & 3.821917808 & 0.0048037 & 0.03455014 \\
\hline $\begin{array}{l}\text { KEGG }_{-} \\
\text {PATHWAY }\end{array}$ & $\begin{array}{l}\text { hsa04623:Cytosolic } \\
\text { DNA-sensing pathway }\end{array}$ & 8 & $\begin{array}{c}5.20 \mathrm{E}- \\
05\end{array}$ & $\begin{array}{l}\text { IL6, IFNB1, IRF7, } \\
\text { IFNA4, NFKBIA, } \\
\text { IFNA8, CXCL10, } \\
\text { ZBP1 }\end{array}$ & 110 & 56 & 7.971428571 & 0.0088 & 0.06341132 \\
\hline \multicolumn{10}{|l|}{ h1n1 down } \\
\hline $\begin{array}{l}\text { KEGG }_{-} \\
\text {PATHWAY }\end{array}$ & hsa05164:Influenza A & 12 & $\begin{array}{c}3.38 \mathrm{E}- \\
10\end{array}$ & $\begin{array}{c}\text { IL6, IFIH1, IRF7, } \\
\text { OAS3, RSAD2, } \\
\text { OAS1, OAS2, CCL5, } \\
\text { MX1, STAT1, IL1A, } \\
\text { CXCL10 }\end{array}$ & 34 & 161 & 13.45560833 & $2.64 \mathrm{E}-08$ & $3.58 \mathrm{E}-07$ \\
\hline $\begin{array}{l}\text { KEGG_- } \\
\text { PATHWAY }\end{array}$ & $\begin{array}{l}\text { hsa05168:Herpes } \\
\text { simplex infection }\end{array}$ & 10 & $\begin{array}{c}1.69 \mathrm{E}- \\
07\end{array}$ & $\begin{array}{l}\text { IFIT1, IL6, IFIH1, } \\
\text { IRF7, TAP1, OAS3, } \\
\text { OAS1, OAS2, CCL5, } \\
\text { STAT1 }\end{array}$ & 34 & 170 & 10.61937716 & $1.32 \mathrm{E}-05$ & $1.79 \mathrm{E}-04$ \\
\hline $\begin{array}{l}\text { KEGG_- } \\
\text { PATHWAY }\end{array}$ & hsa05162:Measles & 9 & $\begin{array}{c}2.42 \mathrm{E}- \\
07\end{array}$ & $\begin{array}{l}\text { IL6, IFIH1, IRF7, } \\
\text { OAS3, OAS1, OAS2, } \\
\text { MX1, STAT1, IL1A }\end{array}$ & 34 & 127 & 12.79342288 & $1.89 \mathrm{E}-05$ & $2.56 \mathrm{E}-04$ \\
\hline $\begin{array}{l}\text { KEGG_} \\
\text { PATHWAY }\end{array}$ & $\begin{array}{c}\text { hsa04620:Toll-like } \\
\text { receptor signaling } \\
\text { pathway }\end{array}$ & 6 & $\begin{array}{c}1.49 \mathrm{E}- \\
04\end{array}$ & $\begin{array}{l}\text { IL6, IRF7, CCL5, } \\
\text { CXCL11, STAT1, } \\
\text { CXCL10 }\end{array}$ & 34 & 97 & 11.16676774 & 0.0115197 & 0.15700528 \\
\hline $\begin{array}{l}\text { KEGG_}_{-} \\
\text {PATHWAY }\end{array}$ & $\begin{array}{l}\text { hsa04623:Cytosolic } \\
\text { DNA-sensing pathway }\end{array}$ & 5 & $\begin{array}{l}2.09 \mathrm{E}- \\
04\end{array}$ & $\begin{array}{l}\text { IL6, IRF7, CCL5, } \\
\text { ZBP1, CXCL10 }\end{array}$ & 34 & 56 & 16.11869748 & 0.0161644 & 0.22075685 \\
\hline $\begin{array}{l}\text { KEGG }_{-} \\
\text {PATHWAY }\end{array}$ & $\begin{array}{l}\text { hsa04668:TNF } \\
\text { signaling pathway }\end{array}$ & 6 & $\begin{array}{c}2.26 \mathrm{E}- \\
04\end{array}$ & $\begin{array}{c}\text { CXCL1, CSF2, IL6, } \\
\text { CXCL2, CCL5, } \\
\text { CXCL10 }\end{array}$ & 34 & 106 & 10.21864595 & 0.0174505 & 0.2384561 \\
\hline $\begin{array}{l}\text { KEGG_- } \\
\text { PATHWAY }\end{array}$ & $\begin{array}{l}\text { hsa04062:Chemokine } \\
\text { signaling pathway }\end{array}$ & 7 & $\begin{array}{c}3.35 \mathrm{E}- \\
04\end{array}$ & $\begin{array}{l}\text { CXCL1, CCR7, } \\
\text { CXCL2, CCL5, } \\
\text { CXCL11, STAT1, } \\
\text { CXCL10 }\end{array}$ & 34 & 180 & 7.020588235 & 0.0258013 & 0.35386457 \\
\hline $\begin{array}{l}\text { KEGG }_{-} \\
\text {PATHWAY }\end{array}$ & hsa05160:Hepatitis C & 6 & $\begin{array}{l}4.18 \mathrm{E}- \\
04\end{array}$ & $\begin{array}{l}\text { IFIT1, IRF7, OAS3, } \\
\text { OAS1, OAS2, STAT1 }\end{array}$ & 34 & 121 & 8.951871658 & 0.0320867 & 0.44129508 \\
\hline
\end{tabular}


role in tissue and organ morphogenesis and in the maintenance of cell and tissue structure and function [17]. The functional macromolecules in the extracellular matrix contained proteoglycans, non-proteoglycan polysaccharide, collagens, fibronectin and laminin and so forth. Several studies have reported the relationship between ECM and viral infections. For example, ECM and interacting proteins involved in the entry of various viruses like gamma-retrovirus, hepatitis B virus and rhabdovirus [18, 19]. Leung, $\mathrm{Li}[20]$ reported that treating cells with anti-fibronectin antibodies or fibronectin-specific small interfering RNA inhibited the $\mathrm{H} 1 \mathrm{~N} 1$ replication, but did not inhibit the $\mathrm{H} 5 \mathrm{~N} 1$ viruses. Moreover, H3N2 virus was able to use intercellular connections to spread to neighboring cells [21]. These reports indicated that $\mathrm{H} 5 \mathrm{~N} 1$ and $\mathrm{H} 1 \mathrm{~N} 1$ replicated with the help of the extracellular matrix in a different manner and the extracellular matrix helped the virus entry, replication, and spread. And according to the functional analysis, H7N9 should be similar to H5N1 in this aspect. Additionally, Chen, Zhou [22] also reported that EMC pathway was involved in H7N9 infection. On the other hand, Chen, Cui [23] found that higher plasma levels of hydrolysis of fibronectin and collagens IV related proteins in survivors of severe H7N9 infection and they hinted the ongoing tissue remodeling after severe H7N9 infection. Thus, the perturbed extracellular matrix pathway in cells might also hint the damaged tissue remodeling of cells, which devastated the fatality.

To summary, we performed a systematic metaanalysis to evaluate the expression profiles in samples infected with H5N1 and H7N9 and we suggested that the extracellular matrix worked positively in the high fatality of H5N1 and H7N9 through affecting viral replication and spread and reducing tissue modeling.

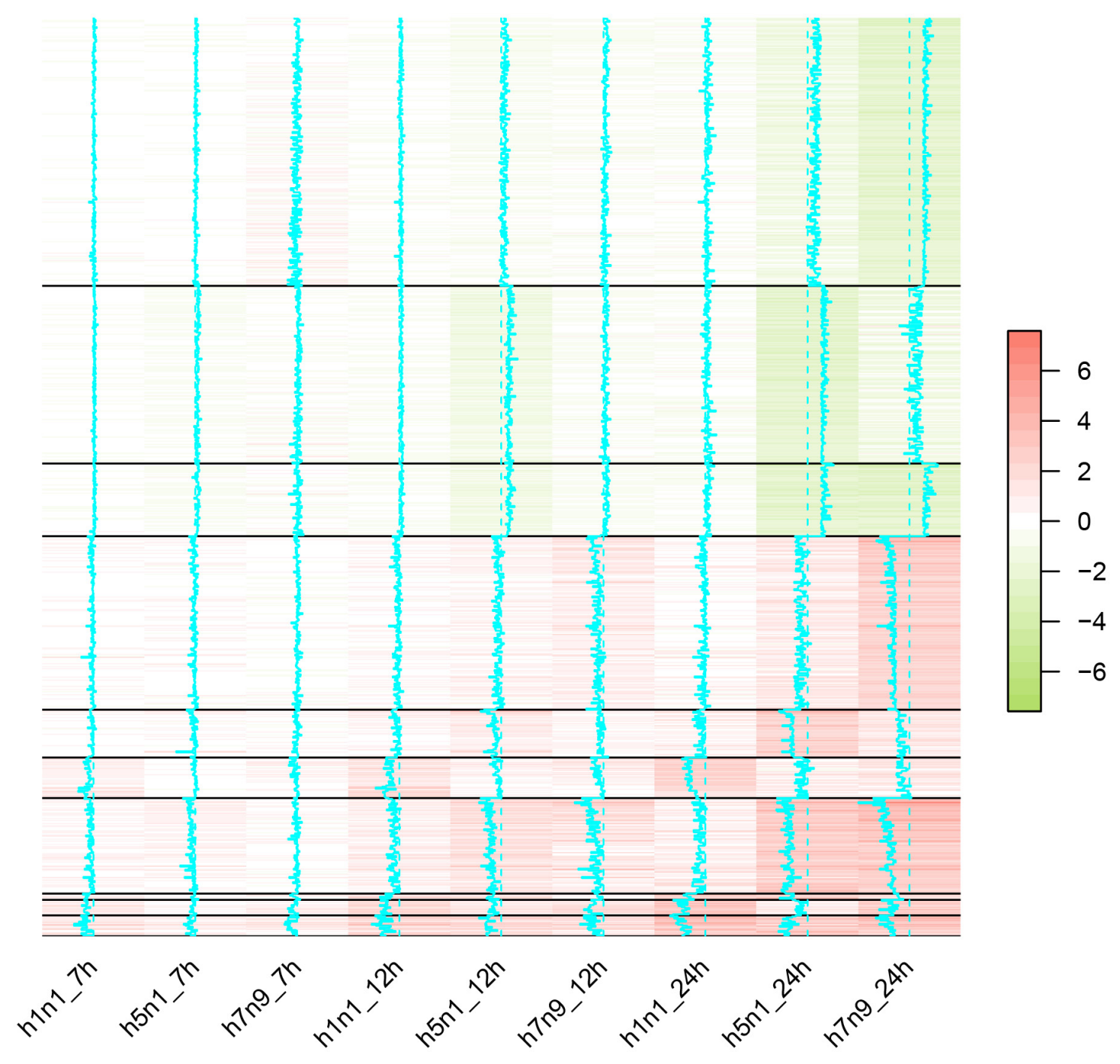

Figure 4: The heatmap of differentially expressed genes in H1N1, H5N1 or H7N9 datasets. Each column represented one virus strain at a time point and each row represented one differentially expressed genes. The distance of the trace line from the center of each color-cell is proportional to the size of the measurement. Different clustering of genes were separated by the solid black lines. 
Table 3: The biological function analysis of genes in each cluster generated by fold change of expression levels in virus-infected samples and controls

\begin{tabular}{|c|c|c|c|c|}
\hline Cluste $^{a}$ & Gene & Attributes & Enriched pathway & $\mathbf{T F}^{\mathrm{b}}$ \\
\hline \multirow{7}{*}{1} & \multirow{7}{*}{258} & \multirow{6}{*}{$\begin{array}{c}\text { down-regulated in } \\
\text { H7N9 }\end{array}$} & Metabolic pathways & \\
\hline & & & Biosynthesis of antibiotics & \\
\hline & & & Carbon metabolism & Pax-5 Sp1 \\
\hline & & & Biosynthesis of amino acids & Egr-1 Egr-2 Hif-1 $\alpha$ \\
\hline & & & Glycolysis/Gluconeogenesis & Ap- $2 \gamma$ \\
\hline & & & N-Glycan biosynthesis & \\
\hline & & \multirow{3}{*}{$\begin{array}{c}\text { down-regulated in } \\
\text { H5N1 }\end{array}$} & Protein processing in endoplasmic reticulum & \\
\hline \multirow{2}{*}{2} & \multirow{2}{*}{171} & & \multirow{2}{*}{ NA } & Creb \\
\hline & & & & $\operatorname{Creb} \beta$ \\
\hline 3 & 70 & $\begin{array}{l}\text { down-regulated in } \\
\text { H5N1 and H7N9 }\end{array}$ & ECM-receptor interaction & NA \\
\hline 4 & 167 & up-regulated in $\mathrm{H} 7 \mathrm{~N} 9$ & NA & NA \\
\hline 5 & 46 & up-regulated in $\mathrm{H} 5 \mathrm{~N} 1$ & NA & NA \\
\hline 6 & 39 & up-regulated in H1N1 & Influenza A & $\begin{array}{l}\text { Irf-7a Irf-1 Irf-10 Irf- } \\
8 \text { Stat5a Stat5b }\end{array}$ \\
\hline 7 & 6 & $\begin{array}{l}\text { up-regulated in H1N1 } \\
\text { and H5N1 }\end{array}$ & NA & NA \\
\hline 8 & 15 & $\begin{array}{l}\text { up-regulated in H1N1 } \\
\text { and H7N9 }\end{array}$ & Influenza A & Irf-1 Irf-10 \\
\hline 9 & 92 & $\begin{array}{l}\text { up-regulated in } \mathrm{H} 5 \mathrm{~N} 1 \\
\text { and H7N9 }\end{array}$ & NA & NA \\
\hline 10 & 20 & up-regulated in all & NA & $\begin{array}{l}\text { Irf-1 Irf-10 Irf-7a } \\
\text { Irf-2 Irf- } 8\end{array}$ \\
\hline
\end{tabular}

a The adjusted p-values by Benjamini method of enriched pathway was lower than 0.05 .

${ }^{\mathrm{b}} \mathrm{TF}$ : transcriptional factors, the association scores of PASTAA was larger than six.

\section{MATERIALS AND METHODS}

\section{Data selection and characteristics}

"H5N1", "H7N9", and "H1N1" were used, respectively, as keyword when search GEO series (https:// www.ncbi.nlm.nih.gov/geo/). The Homo Sapiens and expression profiling by array were used as filtering for the organism and series type. A total of 9 series were available for H5N1, among which 6 series (GSE76599, GSE66597 [24], GSE49840 [25], GSE43203, GSE43204, and GSE28166 [26]) had time series data and were included in this study. Only 2 series (GSE49840 [25] and GSE69026) of H7N9 datasets met our criteria. To compare the host response of highly pathogenic avian influenza with the pandemic H1N1 flu, 2 series of H1N1datasets (GSE80697 and GSE40844) were randomly selected using the same criteria. The virus strains selected in this study were: $\mathrm{A} /$ Vietnam/1203/2004 (H5N1); A/Anhui/01/2013 (H7N9); A/California/04/2009 (H1N1). The detail characteristics of the GEO data series were listed in Table 1. All the datasets were generated with the Agilent platform. To prevent the differences introduced by different methods used in data preprocessing of these series, we downloaded the raw data and processed them using the same procedures. The $R$ package GEOquery [27] was utilized to download the raw Cel files and also the information of each sample. The platform information of every series was retrieved directly from the GEO website. 


\section{Microarray data pre-processing}

The data pre-procession were carried out with the help of the limma package in R software [28]. All the included microarray data used single-channel Agilent platform, so only the intensities of the green channel were extracted. The medians of the foreground and background pixels were calculated as the estimated foreground and background signals. Next, we adjusted the foreground adaptively for the background intensities based on convolution model using the method called 'normexp', which was preferable to background subtraction when assessing differential expressions [29]. Finally, quantile-normalization was applied to the data. Only the mock-infected samples and the samples infected with the targeted influenza were kept into the next step.

\section{Data merge and batch adjustment}

The gene names were mapped to the probes based on the platform information. The expression level of each gene was calculated using the median value of the probes that were mapped to it. The data from different series were merged together according to the gene symbol and any genes missing in any series were excluded. The batch adjustment between different GEO series was completed using package SVA in R software [30]. ComBat function was effective to adjust for known batches using an empirical Bayesian framework [31].

In order to confirm the effects of batch adjustment and also the prerequisite of this meta-analysis study, the expression levels before and after adjustment were visualized using hierarchy clustering and principal component analysis. One series (GSE66597) seemed to be an outlier and was removed in the following study.

\section{Differentially expressed genes identification}

The differentially expressed genes on each time point of all three $\mathrm{H} 5 \mathrm{~N} 1, \mathrm{H} 7 \mathrm{~N} 9$, and $\mathrm{H} 1 \mathrm{~N} 1$ were identified through limma package by comparing the samples with virus infections and with mock infection $[28,32]$. Linear models were fitted and empirical Bayes method was used for statistical analysis and assessing differential expression. The obtained p-values were adjusted by false discovery rate (FDR). The genes with FDR less than 0.01 and absolute log2-fold-change larger than 2 were considered as significantly differentially expressed genes.

The genes that were differentially expressed in any virus strain were extracted and they were clustered based on their logarithm of fold change on three time points in different strains and 10 different clusters were found.

\section{Biological function analysis}

The KEGG pathways were enriched using DAVID Bioinformatics Resources v6.8 [33, 34] for genes upregulated or down-regulated in samples infected with any influenza and for genes belonging to different clusters. HumanGenome in Agilent Backgrounds was selected as population background, considering that all the datasets used Agilent platform. For genes upregulated or down-regulated in $\mathrm{H} 5 \mathrm{~N} 1, \mathrm{H} 7 \mathrm{~N} 9$ or $\mathrm{H} 1 \mathrm{~N} 1$, the p-values were adjusted using Bonferroni methods. However, due to the limited genes in each cluster, the p-values of enriched pathways for different clusters were adjusted using Benjamini method, which is looser than Bonferroni.

The transcription factors binding the genes in each cluster were predicted by PASTAA [35]. Only the transcription factors with an association score larger than 6 were considered as an enriched transcription factor for each cluster.

\section{ACKNOWLEDGMENTS}

The authors would like to thank the contributors of GEO Series GSE76599, GSE66597, GSE49840, GSE43203, GSE43204 and GSE28166 for their sharing of their experimental data in GEO database. This study was supported by grants from Shanghai Natural Science Foundation (16ZR1444000) and the Chinese Research Fund for Non-Profit Research Institutions (2015JB07).

\section{CONFLICTS OF INTEREST}

All authors declared no conflicts of interest in this study.

\section{REFERENCES}

1. Wu ZQ, Zhang Y, Zhao N, Yu Z, Pan H, Chan TC, Zhang ZR, Liu SL. Comparative epidemiology of human fatal infections with novel, high (H5N6 and H5N1) and low (H7N9 and H9N2) pathogenicity avian influenza A viruses. Int J Environ Res Public Health. 2017; 14:E263.

2. Zhao D, Liang L, Wang S, Nakao T, Li Y, Liu L, Guan Y, Fukuyama S, Bu Z, Kawaoka Y, Chen H. Glycosylation of the hemagglutinin protein of $\mathrm{H} 5 \mathrm{~N} 1$ influenza virus increases its virulence in mice by exacerbating the host immune response. J Virol. 2017; 91:e02215-16.

3. World Health Organization. (2017). Human infection with avian influenza A(H7N9) virus - China.

4. World Health Organization. (2017). Emergencies preparedness, response.

5. Peiris JS, de Jong MD, Guan Y. Avian influenza virus (H5N1): a threat to human health. Clin Microbiol Rev. 2007; 20:243-267. 
6. Chen Y, Liang W, Yang S, Wu N, Gao H, Sheng J, Yao H, Wo J, Fang Q, Cui D, Li Y, Yao X, Zhang Y, et al. Human infections with the emerging avian influenza A H7N9 virus from wet market poultry: clinical analysis and characterisation of viral genome. Lancet. 2013; 381:1916-1925.

7. Zaraket H, Baranovich $\mathrm{T}$, Kaplan BS, Carter R, Song MS, Paulson JC, Rehg JE, Bahl J, Crumpton JC, Seiler J, Edmonson M, Wu G, Karlsson E, et al. Mammalian adaptation of influenza A(H7N9) virus is limited by a narrow genetic bottleneck. Nat Commun. $2015 ; 6: 6553$.

8. U.S Food and Drug Administration. (2013). FDA approves first adjuvanted vaccine for prevention of $\mathrm{H} 5 \mathrm{~N} 1$ avian influenza. In: Rodriguez J, ed. FDA News Release.

9. Centers for Disease Control and Prevention. (2017). H7N9: Frequently asked questions.

10. Bresson JL, Perronne C, Launay O, Gerdil C, Saville M, Wood J, Höschler K, Zambon MC. Safety and immunogenicity of an inactivated split-virion influenza A/ Vietnam/1194/2004 (H5N1) vaccine: phase I randomised trial. Lancet. 2006; 367:1657-1664.

11. Ein-Dor L, Kela I, Getz G, Givol D, Domany E. Outcome signature genes in breast cancer: is there a unique set? Bioinformatics. 2005; 21:171-178.

12. Ntzani EE, Ioannidis JP. Predictive ability of DNA microarrays for cancer outcomes and correlates: an empirical assessment. Lancet. 2003; 362:1439-1444.

13. Barrett T, Wilhite SE, Ledoux P, Evangelista C, Kim IF, Tomashevsky M, Marshall KA, Phillippy KH, Sherman PM, Holko M, Yefanov A, Lee H, Zhang N, et al. NCBI GEO: archive for functional genomics data sets--update. Nucleic Acids Res. 2013; 41:D991-995.

14. Castelnuovo M, Zaugg JB, Guffanti E, Maffioletti A, Camblong J, Xu Z, Clauder-Munster S, Steinmetz LM, Luscombe NM, Stutz F. Role of histone modifications and early termination in pervasive transcription and antisensemediated gene silencing in yeast. Nucleic Acids Res. 2014; 42:4348-4362.

15. Qin Q, Zhang C, Zhu H, Yang X, Xu L, Liu J, Lu J, Zhan L, Cheng H, Sun X. Association between survivin-31G>C polymorphism and cancer risk: meta-analysis of 29 studies. J Cancer Res Clin Oncol. 2014; 140:179-188.

16. Ritter JB, Wahl AS, Freund S, Genzel Y, Reichl U. Metabolic effects of influenza virus infection in cultured animal cells: intra- and extracellular metabolite profiling. BMC Syst Biol. 2010; 4:61.

17. Kanehisa M, Furumichi $M$, Tanabe $M$, Sato $Y$, Morishima K. KEGG: new perspectives on genomes, pathways, diseases and drugs. Nucleic Acids Res. 2017; 45:D353-D361.
18. Azab W, Lehmann MJ, Osterrieder N. Glycoprotein H and alpha4beta1 integrins determine the entry pathway of alphaherpesviruses. J Virol. 2013; 87:5937-5948.

19. Singh B, Fleury C, Jalalvand F, Riesbeck K. Human pathogens utilize host extracellular matrix proteins laminin and collagen for adhesion and invasion of the host. FEMS Microbiol Rev. 2012; 36:1122-1180.

20. Leung HS, Li OT, Chan RW, Chan MC, Nicholls JM, Poon LL. Entry of influenza A Virus with a alpha2, 6-linked sialic acid binding preference requires host fibronectin. J Virol. 2012; 86:10704-10713.

21. Roberts KL, Manicassamy B, Lamb RA. Influenza A virus uses intercellular connections to spread to neighboring cells. J Virol. 2015; 89:1537-1549.

22. Chen Y, Zhou J, Cheng Z, Yang S, Chu H, Fan Y, Li C, Wong BH, Zheng S, Zhu Y, Yu F, Wang Y, Liu X, et al. Functional variants regulating LGALS1 (Galectin 1) expression affect human susceptibility to influenza A(H7N9). Sci Rep. 2015; 5:8517.

23. Chen J, Cui G, Lu C, Ding Y, Gao H, Zhu Y, Wei Y, Wang L, Uede T, Li L, Diao H. Severe infection with avian influenza A virus is associated with delayed immune recovery in survivors. Medicine (Baltimore). 2016; 95:e2606.

24. Lin X, Wang R, Zhang J, Sun X, Zou Z, Wang S, Jin M. Insights into human astrocyte response to $\mathrm{H} 5 \mathrm{~N} 1$ infection by microarray analysis. Viruses. 2015; 7:2618-2640.

25. Josset L, Zeng H, Kelly SM, Tumpey TM, Katze MG. Transcriptomic characterization of the novel avian-origin influenza A (H7N9) virus: specific host response and responses intermediate between avian (H5N1 and H7N7) and human $(\mathrm{H} 3 \mathrm{~N} 2)$ viruses and implications for treatment options. mBio. 2014; 5:e01102-01113.

26. Li C, Bankhead A 3rd, Eisfeld AJ, Hatta Y, Jeng S, Chang JH, Aicher LD, Proll S, Ellis AL, Law GL, Waters KM, Neumann G, Katze MG, et al. Host regulatory network response to infection with highly pathogenic H5N1 avian influenza virus. J Virol. 2011; 85:10955-10967.

27. Davis S, Meltzer PS. GEOquery: a bridge between the Gene Expression Omnibus (GEO) and BioConductor. Bioinformatics. 2007; 23:1846-1847.

28. Ritchie ME, Phipson B, Wu D, Hu Y, Law CW, Shi W, Smyth GK. limma powers differential expression analyses for RNA-sequencing and microarray studies. Nucleic Acids Res. 2015; 43:e47.

29. Ritchie ME, Silver J, Oshlack A, Holmes M, Diyagama D, Holloway A, Smyth GK. A comparison of background correction methods for two-colour microarrays. Bioinformatics. 2007; 23:2700-2707.

30. Leek JT, Johnson WE, Parker HS, Jaffe AE, Storey JD. The sva package for removing batch effects and other unwanted 
variation in high-throughput experiments. Bioinformatics. 2012; 28:882-883.

31. Johnson WE, Li C, Rabinovic A. Adjusting batch effects in microarray expression data using empirical Bayes methods. Biostatistics. 2007; 8:118-127.

32. Phipson B, Lee S, Majewski IJ, Alexander WS, Smyth GK. Robust hyperparameter estimation protects against hypervariable genes and improves power to detect differential expression. Ann Appl Stat. 2016; 10:946-963.
33. Huang da W, Sherman BT, Lempicki RA. Bioinformatics enrichment tools: paths toward the comprehensive functional analysis of large gene lists. Nucleic Acids Res. 2009; 37:1-13.

34. Huang da W, Sherman BT, Lempicki RA. Systematic and integrative analysis of large gene lists using DAVID bioinformatics resources. Nat Protoc. 2009; 4:44-57.

35. Roider HG, Kanhere A, Manke T, Vingron M. Predicting transcription factor affinities to DNA from a biophysical model. Bioinformatics. 2007; 23:134-141. 